\title{
The Polish adaptation of the Sociocultural Attitudes Towards Appearance SATAQ 3 Questionnaire
}

\begin{abstract}
BACKGROUND
The importance of mass media (such as radio, television, various magazines, commercials and the Internet) among socio-cultural factors is emphasized and considered as a predictor explaining the preferred and even dictated standard of beauty and attractiveness of the body in the global culture. The SATAQ 3 is a tool designed to measure socio-cultural risk factors of body image disturbance. The purpose of this article is to present the results of many years of research, which was aimed at collecting, analysing and presenting the Polish adaptation and normalization of the SATAQ 3.
\end{abstract}

\section{PARTICIPANTS AND PROCEDURE}

The Polish version of the SATAQ 3 questionnaire used for the research contained 30 items, whose content was identical to the original version of SATAQ 3. The standardization sample consisted of 1505 respondents: women $(n=1044)$ and men $(n=461)$ aged 12 to $64(M=23.65, S D=8.57)$.

\section{RESULTS}

The four factors obtained in the Polish version of the SATAQ 3 questionnaire were named differently than in the
English version of the tool. The Internalization-Pressure scale consists of 12 items and the Internalization-Information Seeking scale consists of 6 items, whereas the Internalization-Athlete scale consists of 4 items and the Information scale consists of 6 items.

\section{CONCLUSIONS}

The present study has shown that SATAQ 3 is a tool with satisfactory statistical reliability. It confirms the usefulness of the tool in both scientific research and screening of adolescents and adults (men and women) in the direction of isolating socio-cultural risk factors of body image disorders and predictors of unhealthy behaviours towards the body and the nutrition.

\section{KEY WORDS}

Polish adaptation; SATAQ 3; Sociocultural Attitudes Towards Appearance

ORGANIZATION - 1: Faculty of Management and Social Communication, Institute of Applied Psychology, Jagiellonian

University, Krakow, Poland · 2: Faculty of Psychology, SWPS University of Social Sciences and Humanities, Katowice, Poland

AUthors' Contributions - A: Study design - B: Data collection - C: Statistical analysis - D: Data interpretation .

E: Manuscript preparation · F: Literature search · G: Funds collection

CORRESPONDING AUthor - Prof. Bernadetta Izydorczyk, Faculty of Management and Social Communication,

Institute of Applied Psychology, Jagiellonian University, 4 Łojasiewicza Str., 30-348 Krakow, Poland,

e-mail: bernadetta.izydorczyk@uj.edu.pl

To CITE this ARTICle - Izydorczyk, B., \& Lizińczyk, S. (2020). The Polish adaptation of the Sociocultural Attitudes Towards

Appearance SATAQ 3 Questionnaire. Health Psychology Report, 8(1), 68-82. https://doi.org/10.5114/hpr.2020.91443

RECEIVED 30.09.2019 • REVIEWED 04.12.2019 • ACCEPTED 14.12.2019 • PUBLISHED 15.01.2020 


\section{BACKGROUND}

In modern literature, many researchers present results of looking for predictors which can explain the socio-cultural genesis of pro-healthy versus unhealthy behaviours of a person towards their body appearance. Meta-analyses of many studies conducted over a dozen years indicate the existence of significant relationship between dissatisfaction with the body image and actions taken by mass media (APA, 2013; Grabe, Ward, \& Hyde, 2008; Levine \& Murnen, 2009). Among the socio-cultural factors, the importance of mass media (such as radio, television, various magazines, commercials and the Internet) is emphasized and considered as a socio-cultural predictor explaining the preferred and even dictated standard of beauty and attractiveness of the body in the global culture (APA, 2013; Bair, Kelly, Serdar, \& Mazzeo, 2012; Cohen \& Blaszczyński, 2015; Cohen, Newton-John, \& Slater, 2017, 2018; Cohen, Fardouly, Newton-John, \& Slater, 2019; Fardouly \& Vartanian, 2015; Fardouly, Pinkus, \& Vartanian, 2017; Mabe, Forney, \& Keel, 2014; McLean, Paxton, Wertheim, \& Masters, 2015; Papadopoulos, 2010; Slater, Cole, \& Fardouly, 2019; Tiggemann \& Brown, 2018; Trojanowska, 2014; Vandenbosch, Vervloessem, \& Eggermont, 2013; Ward, 2016). Considering the growing influence of mass media on body image which was shown in many studies around the world, it is reasonable to assume that there is a need to develop a Polish tool for measuring the level of pressure and above all for describing the internalization of socio-cultural norms towards physical appearance. The psychological diagnosis of the level of internalization of socio-cultural standards is an important element which can help with recognizing distortions of the body image, which are one of the significant risk factors for developing eating disorders. The Sociocultural Attitudes Toward Appearance Questionnaire 3 (SATAQ 3) is a tool designed to measure socio-cultural risk factors of body image disturbance. The purpose of this article is to present the results of many years of research, which was aimed at collecting, analysing and presenting the Polish adaptation and normalization of the Sociocultural Attitudes Towards Appearance Scale 3. The SATAQ 3 questionnaire was developed and published in 2004 by Thompson and his team (Thompson, van den Berg, Roehrig, Guarda, \& Heinberg, 2004). This scale is one of the most popular and at the same time one of the few tools standardized in the USA and Europe for measuring socio-cultural attitudes toward physical appearance (Heinberg, Coughlin, Pinto, \& Guarda, 2008; Knauss, Paxton, \& Alsaker, 2009; Thompson et al., 2004). It is worth mentioning that the Polish normalization of the Body Esteem Scale by Franzoi and Shield was developed and published by Lipowska and Lipowski (2013). However, it is one of the few Polish tools for measuring body image. It was developed on a population of 4298 participants (1865 women aged 16 to 80 years and men aged 16 to 78 years). Nevertheless, the BES scale refers to measuring the body image, without delving into (due to its other purpose) the empirical measurement of the level of pressure and internalization of the standard of attitudes towards the body image and appearance promoted by mass media. The results of many current studies confirm the impact of modern mass media (radio, television, Internet, press, commercials) on the existing and constantly developing phenomenon of sexualization in girls' and women's approach to their own body and physical appearance (APA, 2013; Papadopoulos, 2010; Trojanowska, 2014; Vandenbosch et al., 2013). Increasingly, research also indicates the developing phenomenon of sexualization in the approach to the body in the population of boys and men (Vandenbosch \& Eggermont, 2013). Many well-known scientists have used SATAQ 3 in their own research to measure the level of internalization and pressure of sociocultural norms of body image and physical appearance promoted by mass media (Heinberg et al., 2008; Saunders \& Frazier, 2017; Schaefer, Harriger, Heinberg, Soderberg, \& Thompson, 2017; Tatangelo, McCabe, Mellor, \& Mealey, 2016; Thompson et al., 2004; Uchôa et al., 2019). So far, there is no Polish standardization of a tool for measuring body image and physical appearance standards promoted by mass media. On the other hand, measuring the intensity of the internalization of socio-cultural standards for body image may be an important source of knowledge about socio-cultural predictors of unhealthy (overly restrictive and compulsive) behaviours towards the body and food. These actions are taken in order to match one's physical appearance with current beauty standards. It is worth emphasizing that mass media have a big impact on the development of need for social acceptance and for modelling self-esteem (including body image self-assessment) of adolescent girls and young women (McCabe \& Ricciardelli, 2004; Clark \& Tiggemann, 2008; Izydorczyk \& Rybicka-Klimczyk, 2009; Cash, 2011; Ferguson, Winegard, \& Winegard, 2011; Finne, Bucksch, Lampert, \& Kolip, 2011; Mond, van den Berg, Boutelle, Hannan, \& Neumark-Sztainer, 2011; Gajtkowska, 2013; Józefik, 2014; Izydorczyk, 2015; Czepczor, Kościcka, \& Brytek-Matera, 2016; Głogowska \& Zatorska, 2016). They more often take actions and intensively strive to obtain the obligatory ideal of the female body promoted by mass media, which is usually associated with excessive thinness (Grabe et al., 2008; Ferguson et al., 2011; Cash, 2011; Tiggemann \& Brown, 2018). Consequently, it results in increasing dissatisfaction with one's body and growing risk of developing eating disorders (Rodgers, Chabrol, \& Paxton, 2011; Thomsen, Weber, \& Brown, 2002; Levine \& Murnen, 2009; Tiggemann, 2003; Garner, 2004; Izydorczyk, 2015; Jones \& Crawford, 2006; Żechowski, 2008; Striegel-Moore et al., 2009; Stice et al., 2013). Levine and Smolak (2006) found in their research that women's dissatisfaction with their phys-
The Polish adaptation of the SATAQ 3 
Bernadetta Izydorczyk, Sebastian Lizińczyk ical appearance is related to the person's excessive idealization of the role of slimness (striving for excessive thinness), irrational fear of gaining weight (sometimes manifesting as lipophobia) and belief that weight and body shape are the main determinants of self-identity and self-worth. It is important to note that researchers seeking and explaining the nature of socio-cultural standards of body image and appearance in mass media used various methods to measure described variables (Knauss et al., 2009; Sánchez-Carracedo et al., 2012). However, a Polish adaptation of SATAQ 3 has not been published yet. The first Polish attempts to use SATAQ 3 took place in the research of the author of this article published in 2014 (Izydorczyk, 2014).

The preliminary Polish version of SATAQ 3 was used to conduct a study on a group of 240 healthy women aged 20-26 and on a group of 120 women of the same age but suffering from eating disorders (Izydorczyk, 2014). The psychometric properties of the preliminary Polish version of SATAQ 3 used in 2014 required further statistical analyses on a sufficiently larger (in accordance with statistical requirements) sample of subjects - women and men. It seems important to develop normalization of the SATAQ 3 questionnaire on the Polish population of men and women in order to obtain a tool for measuring the pressure and internalization of body image and physical appearance standards promoted by mass media. The normalization would lead to creating a method which would be comparable to the tools measuring this variable in the world. Furthermore, in the light of the results of numerous studies about the impact of socio-cultural standards on body image in western and highly developed countries, it seems reasonable and valuable to conduct such research in the dynamically developing countries of Central and Eastern Europe, which include Poland. Moreover, research measuring socio-cultural attitudes towards body and physical appearance can also support meta-analyses of many studies conducted around the world, which take different populations into account - including Polish men and women in all ages. The research of the authors of this article was carried out as part of the author's long-term research project, which was conducted over the past few years (20162019) and concerned the search for socio-cultural risk factors for the development of unhealthy behaviours towards the body and the food, which may lead to the development of eating disorders.

\section{ORIGINAL VERSION \\ OF THE SOCIOCULTURAL ATTITUDES TOWARDS APPEARANCE SCALE 3 (SATAQ 3)}

As already mentioned in the background of this article, the Sociocultural Attitudes Towards Appearance Scale 3 (SATAQ 3) is a widely used method for mea- suring the impact of socio-cultural norms promoted by mass media on attitudes and behaviours regarding body and physical appearance. The SATAQ 3 questionnaire is a revision of two previous scales by Heinberg, Thompson, and Stormer (1995) and Thompson, Heinberg, Altabe, and Tantleff-Dunn (1999). This method allows one to check to what extent and how strongly the subject experiences the pressure and internalization of the socio-cultural standard of beauty, attractiveness of the body and physical appearance promoted by mass media (Levine, Smolak, \& Hayden, 1994; Cusumano \& Thompson, 1997; Thompson et al., 2004). SATAQ 3 was developed and published in 2004 by Joel Kevin Thompson, Patricia van den Berg, Megan Roehrig (Department of Psychology, University of South Florida), Leslie J. Heinberg (Department of Psychiatry, Case School of Medicine, Cleveland, Ohio) and Angela S. Guarda (Department of Psychiatry and Behavioral Sciences, Johns Hopkins School of Medicine, Baltimore, Maryland). The SATAQ 3 questionnaire and its earlier versions are useful methods to assess the strength of pressure and internalization of socio-cultural standards of body image and physical appearance. An important advantage of Sociocultural Attitudes Towards the Appearance Questionnaire-3 is its wide application in foreign studies. Moreover, this method has numerous standardizations in the USA (Cusumano \& Thompson, 1997; Heinberg et al., 1995; Heinberg et al., 2008; Thompson et al., 2004) and in Europe (Knauss et al., 2009). Correlation studies showed significant relationships between SATAQ 3 and the measurements of indicators of body image disorders and eating disorders such as body dissatisfaction and striving for excessive thinness (Izydorczyk, 2014). Thompson et al. conducted a study on 175 women aged 17 to 25 , students at the University of South Florida (USA). The authors of the original version of SATAQ 3 conducted explanatory factor analysis on the obtained data and excluded items which were not directly related to the topic of internalization and pressure of socio-cultural norms concerning body image and physical appearance. The questionnaire consists of 30 items to which the examined person should refer using a five-point Likert scale, where 1 means I strongly disagree and 5 means I strongly agree. The reliability of the questionnaire was obtained by calculating Cronbach's alpha. Thompson et al. showed that the 30 items of SATAQ 3 formed a four-factor structure in which each factor describes different types of specific socio-cultural influences on body image and a person's appearance. The results of the questionnaire can be measured for each of the four scales: Internalization-General, Internalization-Athlete, Pressures, Information. The scale of Internalization (which measure the intensity of the general internalization of socio-cultural norms of body image and appearance) consists of 9 items in the original version of the questionnaire. On the other 
hand, the Internalization-Athleticism scale consists of 5 items which refer to internalization of socio-cultural norms promoting an athletic body. However, the scale of Pressure (felt and directly declared pressure of socio-cultural norms) consists of 7 items. The Information scale consists of 8 items. Answers are coded according to the marked points by the examined person. However, some items require the point scale to be reversed. Items $3,6,9,12,13,19,27$ and 28 are reverse-keyed. Thompson et al. made an assumption that along with increase of obtained results the strength of several dimensions would also increase. This mean that the higher the score of the individual scales of SATAQ 3 has been obtained, the higher is the person's level of intensity of the examined factor of mass media influence on the physical appearance (i.e. the level of general internalization of socio-cultural norms, internalization of norms promoting an athletic body, level of felt pressure and frequency of seeking information about body image and appearance). Cronbach's $\alpha$ coefficient calculated for the entire tool was .96. Moreover, internal consistency for individual SATAQ 3 scales also achieved high values: Internalization-General $-\alpha=.96$, Internalization-Athlete $\alpha=.95$, Pressures $-\alpha=.92$, Information $-\alpha=.96$. The percentage of explained variance for this method was $65 \%$. These results confirm that the original version of SATAQ 3 has good psychometric properties. In research reports, Thompson et al. also confirmed good values of parameters such as internal reliability and accuracy of the factors of the SATAQ 3 questionnaire (Thompson et al., 2004).

Another version of the questionnaire, SATAQ 4, was developed by conducting research on different populations of women and men. The tool was presented by Schaefer and his team in 2015. The validation of the SATAQ 4 is based on studies conducted on 859 men and women from the United States. The explanatory factor analysis and structural equation model showed high indicators of statistical validity and reliability. The conducted procedures allowed 22 items to be distinguished. The scale contains five factors: Internalization - Thin/Low body fat, Internalization - Muscular/Athletic, Pressures - Family, Pressures - Peers, Pressures - Media. The structure of the SATAQ 4 questionnaire was confirmed in 3 independent and geographically diverse samples of women from the United States (East Coast $n=440$, West Coast $-n=304$ and North/Midwest $-n=349)$. The survey was also repeated on an international population of 362 women from Italy $(n=159)$, England $(n=110)$ and Australia $(n=93)$. Moreover, a study using the SATAQ 4 questionnaire was also conducted on a group of 271 men (Schaefer et al., 2017). According to the content of 22 items the SATAQ 4 allows the assessment of: the strength of internalization of the ideal body standards (9 items), the strength of internalization of the ideal muscu- lar/athletic appearance (8 items), the need to be attractive and have so-called good physical shape (10 items). The scale of pressure was aimed at assessing the directly felt socio-cultural pressure regarding a person's appearance: peer pressure (8 items), family pressure ( 8 items) and mass media pressure ( 8 items). To sum up, all previous versions of the SATAQ questionnaire (especially SATAQ 3 and SATAQ 4) are characterized by high statistical reliability and validity, which is confirmed by the results of standardization of these methods in the US and in many European countries (Thompson et al., 2004; Schaefer et al., 2017). Obtained data confirm the increase of the impact of socio-cultural factors (especially mass media) on internalization of body image standards, including in the population of Polish men and women. Considering the aforementioned fact, Polish normalization of the SATAQ 3 questionnaire became important not only for conducting scientific research but also screening and detection of the first symptoms of eating disorders.

\section{POLISH ADAPTATION OF THE SOCIOCULTURAL ATTITUDES TOWARDS APPEARANCE SCALE $\left(\right.$ SATAQ 3) ${ }^{1}$}

Polish adaptation began in accordance with the procedures for the cultural adaptation of the psychological test defined by Hornowska and Paluchowski (2004). The author of the original version of the SATAQ 3 questionnaire authorized and allowed research to be conducted using the SATAQ 3 questionnaire for scientific purposes without the need to obtain the copyrights. Construction of the Polish version of SATAQ 3 started in 2007 when independent translators translated the method into Polish (the name of the questionnaire, 30 items of the questionnaire, names of individual subscales and the scale of answers). Subsequently, psychologists who were fluent in English agreed together on a language version. Afterwards, the back translation was done. The two versions were compared to check the accuracy of the translation (Hornowska \& Paluchowski, 2004). The translation turned out to be very similar to the content of the original tool. The respondents give answers on a Likert scale, which contains options from 1 (strongly disagree) to 5 (strongly agree). Content regarding the internalization of socio-cultural norms of physical appearance described the level of its conscious and unconscious assimilation (by making continuous comparison and selection of those which are necessary for a person's functioning). Those standards promoted by mass media indicate how to be attractive and how an appealing body and physical appearance should look like. Participants of the research by using a descriptions assess
The Polish adaptation of the SATAQ 3 
Bernadetta Izydorczyk, Sebastian Lizińczyk the level of their dependence on the influence of socio-cultural norms on their body image and physical appearance, and their behaviour towards it in three areas: internalization, felt pressure and frequency of consciously declared reception and seeking information about promoted standards of physical appearance of the female body. A group of 1511 people were tested using this method. Six people were disqualified from the research due to the lack of correct completion of the SATAQ 3 and failure to meet the selection criteria for the research group (eating disorders, other mental and/or physical disorders associated with the occurrence of body image distortions or physical disability). The research group consisted of 1505 people.

\section{CHARACTERISTICS OF THE POLISH RESEARCH GROUP}

The research was conducted from 2016 to 2019 in several Polish provinces. The entire cycle of research was carried out at the same time in a population of adults and in a population of adolescents in 5 cities with academic centres (at least one university). Persons were recruited for research from students (men and women) of several universities (faculties: humanities, social sciences, exact science, biology and chemistry), employed persons, and students of high schools and middle schools. Three groups of interviewers conducted research at the same time. The first and second group of trained interviewers consisted of psychology students (participants of the master seminar of the author of this article in 2016-2019) and people who had already graduated from university and had various professional status (they worked professionally, had various forms of employment or currently did not have a job). The third group of trained interviewers obtained data by using SATAQ 3 in a population of girls aged 12 to

\section{Table 1}

Percentage distribution of participants of the study in terms of age and gender $(N=1505)$

\begin{tabular}{lccc}
\hline & Women & Men & All \\
\hline $12-16$ & 251 & 29 & 280 \\
$\%$ & 24.04 & 6.29 & \\
$17-20$ & 188 & 134 & 322 \\
$\%$ & 18.01 & 29.07 & \\
21 and above & 605 & 298 & 903 \\
$\%$ & 57.95 & 64.64 & \\
All & 1044 & 461 & 1505 \\
\hline
\end{tabular}

17, recruited from among 4 middle schools and high schools.

As mentioned above, the entire cycle of research was conducted in 2016-2019 during the implementation of the research project about psychological and socio-cultural conditioning of attitudes towards the body. The interviewers trained in conducting psychological research (graduate students) conducted study in individual contact using the Polish version of SATAQ 3, which was prepared and translated according to the standards of construction of psychological tests (Hornowska \& Paluchowski, 2004). All participants were informed about the purpose of the research and that participation in the study was voluntary and anonymous. The standardization sample consisted of 1505 respondents: women $(n=1044)$ and men $(n=461)$ aged 12 to $64(M=23.65, S D=8.57)$ The following variables were monitored in the study: age, gender and BMI. The criteria for exclusion from the study were: declaration of having eating disorders in their life history (medical diagnosis of anorexia, bulimia, binge-eating disorder and treatment for the abovementioned reason) mental disorders requiring different forms of treatment (in clinics, hospitals and other health care facilities), people with body deformation caused by various physical disabilities. Characteristics of the group in terms of gender, age of life with regard to perspective of body image development (from the period of adolescence to the period of young adulthood and mature age) and the BMI are presented below in Table 1 .

The results show that the largest part of the group are men and women aged 21 and above (58\% of women and $65 \%$ of men). Among younger people, the majority of the group are women who are 12-16 years old $(n=251,24 \%$ of all examined women), not men ( $n=29,6.3 \%$ of all examined men). The results confirm that among examined men by far the most are in the group of young adults (21 years and above). In turn, the group of women is also dominated by adults. It is also noticeable that in the age category of adolescents and young adults, women predominated.

Table 2 presents the distribution of intensity of mean values in terms of such characteristics as weight, height, BMI, age and average intensity of the SATAQ 3 questionnaire scale in the population of examined women and men.

Statistical analysis confirms that in the studied population of women, the average age is 23 and the average BMI is 21.34, which is the normal weight range. The analysis of average values in the group of men indicates that men were slightly older than 25 years, i.e. they had a higher average age than women $(M=23.05)$. Men also had higher BMI scores - $M=24.02$, which is the upper limit of normal weight. In the case of women, the BMI was near the lower limit of the normal weight range. 
Table 2

Descriptive statistics of examined men and women in terms of weight, height, BMI, age and subscales of SATAQ 3 questionnaire $(N=1505)$

\begin{tabular}{|c|c|c|c|c|c|}
\hline Variables & $M$ & Me & Min & Max & $S D$ \\
\hline \multicolumn{6}{|l|}{ Women } \\
\hline weight & 61.60 & 60.00 & 37.00 & 116.00 & 9.88 \\
\hline height & 167.00 & 167.00 & 150.00 & 186.00 & 5.58 \\
\hline age & 23.05 & 21.00 & 12.00 & 61.00 & 8.40 \\
\hline BMI & 21.34 & 20.76 & 15.40 & 46.80 & 3.05 \\
\hline \multicolumn{6}{|l|}{ Men } \\
\hline weight & 82.47 & 81.00 & 48.00 & 159.00 & 14.53 \\
\hline height & 177.62 & 178.00 & 153.00 & 210.00 & 8.03 \\
\hline age & 25.03 & 23.00 & 16.00 & 63.00 & 8.81 \\
\hline $\mathrm{BMI}$ & 24.02 & 24.06 & 17.71 & 42.90 & 3.97 \\
\hline
\end{tabular}

\section{PSYCHOMETRIC PROPERTIES OF THE POLISH VERSION OF THE SATAQ 3 QUESTIONNAIRE}

In order to examine the psychometric properties of the adapted Polish version of SATAQ 3 confirmatory and exploratory factor analyses were performed. Afterwards, the reliability coefficients were calculated and descriptive statistics were checked. All analyses were performed using two statistical programs: Statistica 10.0 and SPSS for Windows 23.0.

\section{FACTOR STRUCTURE OF THE QUESTIONNAIRE}

Following the authors of the original version of the tool (Thompson et al., 2004), at the initial stage of statistical analyses, a confirmatory factor analysis (CFA) was carried out, taking into account the original factoral structure of the SATAQ 3. The results did not confirm that the raw data collected mapped the original factor matrix. For this reason, the decision was made to use exploratory factor analysis (EFA). This analysis was performed using the principal components method, which was subjected to Varimax rotation with normalization, which allows the existence of a correlation between individual factors, but does not exclude the lack of correlation and Kaiser normalization. The obtained results of pilot studies were subjected to reliability analysis. The measure of compliance of the sample was: $\mathrm{KMO}=.92$. Bartlett's sphericity test result allows one to reject the hypothesis of a unit matrix $\left(\chi^{2}=23601.00, d f=435, p<.001\right)$. The results clearly indicate that this tool consists of subscales and does not have a homogeneous factor structure. This justified the next analysis. The exploratory factor analysis indicated that both the Kaiser-

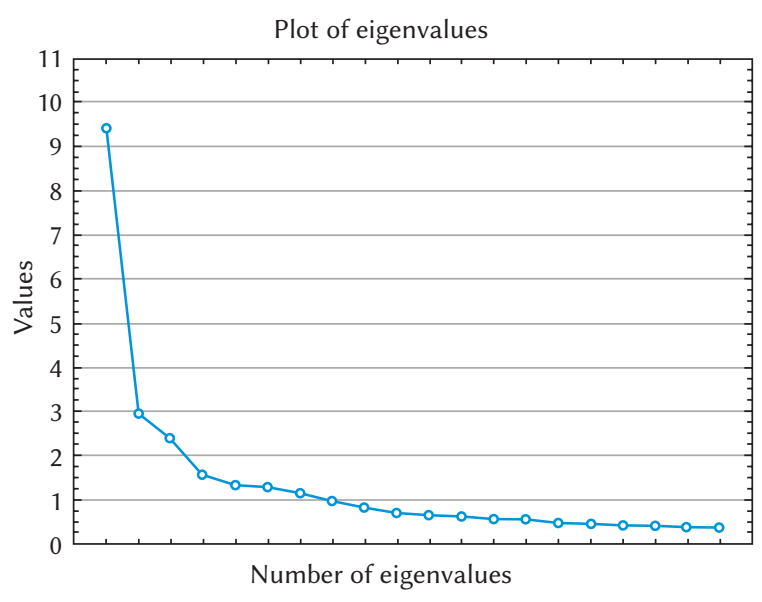

Figure 1. Plot of eigenvalues for SATAQ 3 questionnaire.

Guttman criterion (loads above the value of 1) and the results of analyses of the plot of eigenvalues justified the adoption of a four-factor solution (see Figure 1). Four factors were identified based on the above-mentioned analyses. These four factors explained $58 \%$ of variance of the collected results. The extracted subscales are characterized by high factor loadings in the range of $0.50-0.80$. The aim was to obtain the greatest similarity between the Polish adaptation and the original version of SATAQ 3 in the value of factor loadings. This was an additional criterion which allowed the final adoption of the four-factor structure of the SATAQ 3 questionnaire in Polish studies.

Four factors were identified as a result of factor analysis. The table below presents the obtained matrix of factor loadings of the analysed questionnaire (see Table 3).
The Polish adaptation of the SATAQ 3 
Table 3

Factor loadings of the Polish version of the Sociocultural Attitudes Towards the Body Appearance SATAQ 3 Questionnaire - results of exploratory factor analysis $(n=1505)$

\begin{tabular}{|c|c|c|c|c|}
\hline Items & Factor 1 & Factor 2 & Factor 3 & Factor 4 \\
\hline 2. I've felt pressure from TV or magazines to lose weight. & .42 & .28 & -.31 & .02 \\
\hline 4. I compare my body to the bodies of people who are on TV. & .66 & -.06 & .23 & .25 \\
\hline $\begin{array}{l}\text { 7. I would like my body to look like the models who appear } \\
\text { in magazines. }\end{array}$ & .71 & -.01 & .24 & .10 \\
\hline $\begin{array}{l}\text { 8. I compare my appearance to the appearance of TV } \\
\text { and movie stars. }\end{array}$ & .70 & -.03 & .28 & .21 \\
\hline 10. I've felt pressure from TV and magazines to be thin. & .76 & -.07 & -.01 & .32 \\
\hline 11. I would like my body to look like the people who are in movies. & & .02 & .19 & -.03 \\
\hline 14. I've felt pressure from TV or magazines to have a perfect body. & .76 & -.09 & -.00 & .30 \\
\hline 15. I wish I looked like the models in music videos. & .71 & .02 & .19 & .21 \\
\hline $\begin{array}{l}\text { 16. I compare my appearance to the appearance of people } \\
\text { in magazines. }\end{array}$ & .71 & .00 & .20 & .35 \\
\hline 18. I've felt pressure from TV or magazines to diet. & .73 & -.04 & -.01 & .34 \\
\hline 22. I've felt pressure from TV or magazines to exercise. & .65 & -.07 & -.05 & .27 \\
\hline $\begin{array}{l}\text { 26. I've felt pressure from TV or magazines to change my } \\
\text { appearance. }\end{array}$ & .71 & -.05 & .01 & .39 \\
\hline 6. I do not feel pressure from TV or magazines to look pretty. & -.06 & .63 & -.04 & -.13 \\
\hline $\begin{array}{l}\text { 9. Music videos on TV are not an important source } \\
\text { of information about fashion and "being attractive." }\end{array}$ & -.05 & .50 & -.02 & .14 \\
\hline $\begin{array}{l}\text { 12. Magazine articles are not an important source } \\
\text { of information about fashion and "being attractive." }\end{array}$ & .09 & .67 & -.09 & -.26 \\
\hline 13. I've felt pressure from TV or magazines to have a perfect body. & -.02 & .76 & -.010 & -.01 \\
\hline 27. I do not try to look like the people on TV. & .01 & .76 & -.06 & -.05 \\
\hline $\begin{array}{l}\text { 28. Movie stars are not an important source of information } \\
\text { about fashion and "being attractive." }\end{array}$ & -.10 & .70 & -.00 & .04 \\
\hline 20. I compare my body to that of people in "good shape." & .28 & -.04 & .68 & .05 \\
\hline 23. I wish I looked as athletic as sports stars. & .15 & -.02 & .71 & -.04 \\
\hline 24. I compare my body to that of people who are athletic. & .21 & .04 & .82 & .12 \\
\hline 30. I try to look like sports athletes. & .01 & -.01 & .79 & .08 \\
\hline $\begin{array}{l}\text { 1. TV programs are an important source of information about } \\
\text { fashion and "being attractive." }\end{array}$ & .32 & -.04 & .01 & .67 \\
\hline $\begin{array}{l}\text { 5. TV commercials are an important source of information } \\
\text { about fashion and "being attractive." }\end{array}$ & .22 & .02 & .06 & .78 \\
\hline $\begin{array}{l}\text { 17. Magazine advertisements are an important source } \\
\text { of information about fashion and "being attractive." }\end{array}$ & .35 & .04 & .06 & .76 \\
\hline $\begin{array}{l}\text { 21. Pictures in magazines are an important source } \\
\text { of information about fashion and "being attractive." }\end{array}$ & .39 & .02 & .06 & .76 \\
\hline $\begin{array}{l}\text { 25. Movies are an important source of information about } \\
\text { fashion and "being attractive." }\end{array}$ & .45 & .01 & .10 & .63 \\
\hline $\begin{array}{l}\text { 29. Famous people are an important source of information } \\
\text { about fashion and "being attractive." }\end{array}$ & .44 & .03 & .14 & .57 \\
\hline
\end{tabular}

Bernadet Izydorczyk, Sebastian Lizińczyk 
Table 4

Total explained variance for identified factors of SATAQ 3 questionnaire

\begin{tabular}{lccc}
\hline Factor & \multicolumn{3}{c}{ Principal components } \\
\cline { 2 - 4 } & Eigenvalues & $\begin{array}{c}\text { Proportion } \\
\text { of variance }(\%)\end{array}$ & $\begin{array}{c}\text { Cumulative } \\
\text { variance }(\%)\end{array}$ \\
\hline 1. Internalization-Pressure & 9.41 & 31.40 & 31.40 \\
2. Internalization-Information & 2.95 & 9.80 & 41.20 \\
$\quad$ Seeking & & & 49.20 \\
3. Internalization-Athlete & 2.39 & 8.00 & 54.40 \\
4. Information & 1.57 & 5.20 & \\
\hline
\end{tabular}

The Polish adaptation of the SATAQ 3
The obtained results of factor analysis and unsatisfactory low values of factor loadings for the identified factors in items No. $3(0.039-0.251)$ and No. 9 (-0.013-0.164) caused the exclusion of these items from the Polish version of the SATAQ 3 questionnaire. Next, an estimation of the degree of explained variance of the collected results was made in connection with the identification of the four-factor structure of the tool. The analysis of the values mentioned above showed satisfactory results and justified the identification of four factors in the Polish version of the SATAQ 3 questionnaire. The detailed results of this analysis are presented in Table 4 .

The total value of the explained variance $(54.4 \%)$ is lower than in the original version of the tool $(65 \%)$. However, in order to understand this difference one should consider that the selection of the Polish research group was different and broader than in the original research. Thompson et al. (2004) conducted a study on a homogeneous research group in terms of sex, education and age (women aged 17 to 25 years, students). The sample of participants in the Polish population was definitely more heterogeneous in terms of sex (it included women and men), education (high school students, university students, people who work professionally) and age (broad spectrum of age from period of early adolescence, i.e. 12 years old to the period of old age).

\section{CHARACTERISTICS OF THE SCALES OF THE POLISH VERSION OF THE SATAQ 3 QUESTIONNAIRE}

After analysing the plot of eigenvalues and comparing the obtained explained variance, it was decided to adopt the four-factor structure of the tool. The adoption of such design of the tool was dictated by the original assumption of the authors of the original version of the SATAQ 3 questionnaire as well as by the fact that four factors explained over $54 \%$ of explained variance of the dependent variable. Due to the similarity of content contained in the factors including items in original and Polish versions, it was decided to name each factor in the scales as presented below:

- Factor I Internalization-Pressure - scale describes the level of internalization of socio-cultural norms regarding the body image and physical appearance of a person, which is a result of directly felt pressure of standards promoted in mass media such as television, radio, Internet, magazines and commercials.

- Factor II Internalization-Information Seeking scale describes the level of internalization regarding body image and physical appearance of a person, which is a result of seeking information about body image.

- Factor III Internalization-Athlete - scale describes the level of internalization of socio-cultural norms regarding the body image and physical appearance of a person. It refers specifically to the assessment of the intensity of the need to have a fit and athletic body.

- Factor IV Information - scale describes the level of frequency of searching for information about body image and appearance in the mass media.

The four factors obtained in the Polish version of the SATAQ 3 questionnaire were named differently than in the English version of the tool. The Internalization-Pressure scale consists of 12 items, the Internalization-Information Seeking scale consists of 6 items, the Internalization-Athlete scale consists of 4 items, and the Information scale consists of 6 items.

It seems important to refer to research of Thompson et al. (2004), because of the differences in both studies regarding the results of factor analysis. They show differences between the studied population in terms of factors classified as scales in Polish and English versions of SATAQ 3. Four homogeneous factors were identified in the research of Thompson et al. (2004): Internalization-General, InternalizationAthlete, Pressures and Information. Two mixed factors have been distinguished in the Polish version of 
Bernadetta Izydorczyk, Sebastian Lizińczyk
SATAQ 3. Factor I - Internalization-Pressure contains an equal number of items which describe at the same time the pressure of socio-cultural norms and internalization of socio-cultural norms of body image and physical appearance. Factor II - InternalizationInformation Seeking contains items describing internalization of the socio-cultural norms regarding body image and physical appearance, which is a result of searching for information about beauty standards without being aware of pressure of these standards on a person's body image and physical appearance. Factor III - Internalization-Athlete was named as in the original version of SATAQ 3 by Thompson et al., because it turned out that this factor has similar composition of items as in the English version of the tool. This factor describes the level of internalization of socio-cultural norms promoting a fit body. Factor IV in both the Polish and the English version is called Information. It has the same structure of items in both versions of the questionnaire. This factor describes the frequency of searching for information on body image standards and physical appearance.

\section{VALIDITY AND RELIABILITY ANALYSIS OF THE SATAQ 3 QUESTIONNAIRE}

The obtained values of Cronbach's $\alpha$ coefficients exceeded the value of .70, which is an acceptable result (Hornowska \& Paluchowski, 2004). Due to this fact, it is verified that the Sociocultural Attitudes Towards Appearance Questionnaire (SATAQ 3) is characterized by satisfactory reliability (Table 5). Cronbach's $\alpha$ coefficients were satisfactory for individual subscales of the tool in the studied population of Polish men and women. They ranged between .76 and .92. It is worth mentioning that the obtained Cronbach's $\alpha$ coefficients were slightly different than in the original version. It is difficult to explicitly compare the obtained reliability coefficients to the English version of the tool due to the fact that the Polish version of SATAQ 3 is not a full reproduction of the English version. The Cronbach's $\alpha$ coefficients for the identified subscales ranged from .92 to .96 in the original version of the tool. Therefore, they were higher than those obtained in the Polish standardization study.

The next step of the analysis involved measuring basic descriptive statistics for the four identified factors of the tool. Detailed results are presented in the table below.

The analysis of the obtained results indicates that the highest results were obtained for the internalization of socio-cultural norms regarding body image and physical appearance, which occurs in relation to the explicitly declared pressure of these norms promoted by the mass media. The level of the Internalization-Pressure clearly dominates over the intensity of other forms of socio-cultural influence of mass media on body image and physical appearance. The second factor showing the highest level of impact of mass media on body image is a factor related to the search for information about body image and physical appearance and associated internalization of these socio-cultural norms. The other two dimensions (Information and Internalization-Athlete) turned out to be less significant in the studied population than the other two variables (two sources of socio-cultural impact on body image).

Due to the identification of the four-factor structure of the tool and due to the assumption that the gender of the subjects significantly determines the level of identified factors, the characteristics of the group of women and men were measured. Comparison of descriptive characteristics of the subscales of SATAQ 3 for the group of girls, women and men revealed noticeable differences in the intensity of variables. In the case of Internalization General and Information, the mean values were higher in the group of women than in the group of men. On the other hand, men obtained higher results of mean value in the scale of Pressures and Internalization-Athlete. The authors of this study assumed that gender would significantly affect the level of the variables included in the SATAQ 3 questionnaire. Subsequently, com-

Table 5

Reliability coefficients and descriptive statistics of total results for individual subscales of SATAQ 3

\begin{tabular}{lccccccc}
\hline Factors & $\begin{array}{c}\text { Number of } \\
\text { questions }\end{array}$ & $\begin{array}{c}\text { Cronbach's } \\
\alpha\end{array}$ & $M$ & Me & Min & Max & $S D$ \\
\hline $\begin{array}{l}\text { 1. Internalization- } \\
\quad \text { Pressure }\end{array}$ & 12 & .92 & 27.90 & 26.00 & 12.00 & 60.00 & 11.66 \\
$\begin{array}{l}\text { 2. Internalization- } \\
\text { Information Seeking }\end{array}$ & 6 & .76 & 19.11 & 19.00 & 6.00 & 30.00 & 6.04 \\
$\begin{array}{l}\text { 3. Internalization- } \\
\text { Athlete }\end{array}$ & 4 & .80 & 11.15 & 11.00 & 4.00 & 20.00 & 4.23 \\
4. Information & 6 & .89 & 12.31 & 12.00 & 6.00 & 30.00 & 5.70 \\
\hline
\end{tabular}


Table 6

Comparative analysis of subscales of the SATAQ 3 questionnaire for the groups of women and men

\begin{tabular}{|c|c|c|c|c|c|c|c|}
\hline \multirow[t]{2}{*}{ Variables } & \multicolumn{2}{|c|}{ Women } & \multicolumn{2}{|c|}{ Men } & \multirow[t]{2}{*}{$t$} & \multirow[t]{2}{*}{$d f$} & \multirow[t]{2}{*}{$p$} \\
\hline & $M$ & $S D$ & $M$ & $S D$ & & & \\
\hline Internalization General & 29.71 & 11.73 & 23.77 & 10.37 & 9.38 & 1503 & $<.001$ \\
\hline Pressures & 18.49 & 5.60 & 20.54 & 6.74 & -6.14 & 1503 & $<.001$ \\
\hline Internalization-Athlete & 10.83 & 4.03 & 11.85 & 4.57 & -4.36 & 1503 & $<.001$ \\
\hline Information & 13.32 & 5.77 & 9.97 & 4.76 & 10.95 & 1503 & $<.001$ \\
\hline
\end{tabular}

parison between the group of men and women was made. Due to the presence of the normal distribution, the $t$-test was used in further analysis. The Table 6 contains a detailed summary of the obtained results.

The obtained data confirm the presence of significant differences in the intensity of studied variables. Significant differences were found in all compared variables. Women have significantly higher results on the scales of Internalization (Internalization-General) and Information. However, men are characterized by higher intensity of such scales as Pressures and Internalization-Athlete. For this reason, it seems reasonable to define separate standards for the studied population of men and women.

\section{NORMALIZATION}

The last element of the statistical analysis of the SATAQ 3 questionnaire was the assignment of raw scores to appropriate values of the sten scale. The
Polish norms of the SATAQ 3 questionnaire were developed separately for women and men, because the research showed that the intensity of the impact of socio-cultural norms on body image and physical appearance depends on the gender of the person. Tables 7 and 8 present the sten norms for the groups of women and men.

\section{DISCUSSION}

Polish adaptation and normalization of SATAQ 3 has similar reliability and statistical characteristics to the original version of the tool developed by Thompson et al. (2004). Table 9 presents the comparison between the Polish and original version of the tool in the form of a list of identified factors (subscales) and all the items assigned to each factor. It is important to mention that there were differences between the original and Polish version of SATAQ 3 in terms of strength of the factor loadings and the number

Table 7

Sten norms of SATAQ 3 questionnaire for women

\begin{tabular}{lcccc}
\hline Sten & $\begin{array}{c}\text { Scale 1 } \\
\text { Internalization- } \\
\text { Pressure }\end{array}$ & $\begin{array}{c}\text { Scale 2 } \\
\text { Internalization- } \\
\text { Information Seeking }\end{array}$ & $\begin{array}{c}\text { Scale 3 } \\
\text { Internalization- } \\
\text { Athlete }\end{array}$ & $\begin{array}{c}\text { Scale 4 } \\
\text { Information }\end{array}$ \\
\hline 1 & $0-10$ & $0-8$ & $0-3$ & $0-4$ \\
2 & $11-13$ & $9-11$ & $4-5$ & 5 \\
3 & $14-19$ & $12-14$ & $6-7$ & $6-8$ \\
4 & $20-24$ & $15-17$ & $8-10$ & $9-10$ \\
5 & $25-30$ & $18-20$ & $11-12$ & $11-13$ \\
6 & $31-36$ & $21-23$ & $13-14$ & $14-16$ \\
8 & $37-42$ & $24-26$ & $15-16$ & $17-19$ \\
9 & $43-48$ & $27-29$ & $17-18$ & $20-22$ \\
10 & $49-54$ & 30 and above & 19 and above & $23-25$ \\
\hline
\end{tabular}


Table 8

Sten norms of SATAQ 3 questionnaire for men

\begin{tabular}{rlcccc} 
& Sten & Scale 1 & Scale 2 & Scale 3 & Scale 4 \\
\cline { 2 - 5 } & 1 & $0-11$ & $0-8$ & $0-3$ & $0-5$ \\
& 2 & $12-13$ & $9-11$ & $4-5$ & $6-8$ \\
& 3 & $14-19$ & $12-14$ & $6-7$ & $9-10$ \\
Bernadetta & 5 & $20-24$ & $15-17$ & $8-10$ & $11-13$ \\
Izydorczyk, & 6 & $25-30$ & $18-20$ & $11-12$ & $14-16$ \\
Sebastian & 7 & $31-36$ & $21-23$ & $13-14$ & $17-19$ \\
Lizińczyk & 8 & $37-42$ & $24-26$ & $15-16$ & $20-22$ \\
& 9 & $43-48$ & $27-29$ & $17-18$ & $23-24$ \\
\end{tabular}

of items belonging to the four distinguished factors (according to the conducted exploratory factor analysis). Due to the distribution of factor loadings and belongingness of items to one of the four factors, it was necessary to redefine the original names of factor I and II created by Thompson et al. (2004). The distribution of items in factor I and II in the Polish version of the SATAQ 3 questionnaire was not identical to the distribution of the items in these factors in the original version of the tool. The InternalizationGeneral scale has 9 items (questions 3, 4, 7, 8, 11, 12, $15,16,27)$ and the Pressure scale has 7 items $(2,6,10$, 14, 18, 22, 26) in the English version of the tool. This case is different in the Polish adaptation. Important differences between the Polish and the original version of SATAQ 3 have been identified. In the Polish adaptation, Factor I includes items which describe at the same time the level of internalization and the intensity of pressure of socio-cultural norms, whereas Factor II contains items describing the level of the internalization of socio-cultural norms and seeking the information on body image and appearance. Factor I contains 12 items - including 6 items which describe the level of global internalization and 6 items describing the level of perceived pressure of sociocultural norms regarding body image and appearance. Summarizing, factor II is created by 6 items -3 items describe the level of searching information about body image and appearance in mass media and 3 items describe the level of internalization of socio-cultural norms. Due to the internal differences in the content of items of factor I and II, the names of these scales - Internalization-General and Pressure were redefined in the Polish adaptation of SATAQ 3. According to the content of the items, factor I was called Internalization-Pressure (it describes the level of pressure of socio-cultural norms declared by a person and internalization of socio-cultural norms regarding body image and appearance). The content of 12 items of factor I match with some of the scales Internalization-General and Pressure from the original version of SATAQ 3 developed by Thompson et al. (2004). On the other hand, Factor II was called Internalization-Information Seeking in the Polish adaptation, because it allows one to describe the level of searching for information about body image and appearance ( 3 items) and internalization of the socio-cultural norms promoted by mass media (3 items). Due to the identity of the items with the original version, the Internalization-Athlete scale is included in both Polish and English versions of SATAQ 3. However, this scale contains 6 items in the original version and only 4 items in the Polish version. The fourth scale in the original version of SATAQ 3 is called Information and has 9 items. The Polish adaptation contains 6 items, which concurred with the original version created by Thompson et al. (2004). All these items describe the level of frequency of searching for information on body image and appearance. Factors III and IV are similar in both versions of SATAQ 3. A comparison between English and Polish versions is presented in Table 9.

To sum up, description and comparison of the items belonging to four factors of the Polish adaptation of SATAQ 3 show that:

- Factor I contains items which characterize the measurement of the intensity of internalization of socio-cultural norms regarding the body image and physical appearance promoted by mass media. It is important to mention that it is a result of directly declared and realized pressure of norms promoted by mass media on the person.

- The content of Factor II is also characterized by the level of internalization of socio-cultural norms 
Table 9

List of items included in Polish and English version of SATAQ 3 questionnaire

\begin{tabular}{|c|c|c|c|}
\hline Factor & $\begin{array}{l}\text { Items } \\
\text { (original version) }\end{array}$ & Factor & $\begin{array}{l}\text { Items } \\
\text { (Polish version) }\end{array}$ \\
\hline $\begin{array}{l}\text { Internalization- } \\
\text { General }\end{array}$ & $\begin{array}{l}3,4,7,8,11,12,15,16 \\
27 \text { (9 items) }\end{array}$ & $\begin{array}{l}\text { Internalization- } \\
\text { Pressure }\end{array}$ & $\begin{array}{l}2,4,7,8,10,11,14,15,16,18 \\
22,26(12 \text { items })\end{array}$ \\
\hline Pressure & $\begin{array}{l}2,6,10,14,18,22,26 \\
\text { ( } 7 \text { items) }\end{array}$ & $\begin{array}{l}\text { Internalization- } \\
\text { Information Seeking }\end{array}$ & $6,9,12,13,27,28$ (6 items) \\
\hline $\begin{array}{l}\text { Internalization- } \\
\text { Athlete }\end{array}$ & $\begin{array}{l}19,20,23,24,30 \\
\text { (5 items) }\end{array}$ & $\begin{array}{l}\text { Internalization- } \\
\text { Athlete }\end{array}$ & $20,23,24,30$ (4 items) \\
\hline Information & $\begin{array}{l}1,5,9,13,17,21,25,28, \\
29 \text { (9 items) }\end{array}$ & Information & $1,5,17,21,25,29$ (6 items) \\
\hline
\end{tabular}

The Polish adaptation of the SATAQ 3 about body image and appearance which are promoted by mass media. However, these items also describe the conscious declaration of seeking information about beauty standards and body image without feeling the pressure of socio-cultural norms spread by mass media.

- Factor III consists of similar items in both Polish and English versions of the SATAQ 3. This scale measure the internalization of athletic and fit body image norms.

- Factor IV has the same name in both Polish and English versions of the tool. It also consists of similar items, which describe the intensity of conscious searching for information on body image and appearance.

Due to the similarity between the content of items which belong to factors III and IV in both Polish and English versions of SATAQ 3, it was decided to preserve the original names of the scales: Factor III - Internalization-Athlete and Factor IV - Information.

\section{CONCLUSIONS}

The presented studies have shown that SATAQ 3 is a tool with satisfactory statistical reliability. It confirms the usefulness of the tool in both scientific research and screening of adolescents and adults (men and women) aimed at isolating socio-cultural risk factors of body image disorders and predictors of unhealthy behaviours towards the body and nutrition. Standardization studies conducted on a population of 1505 Polish people have allowed the development of standards that make it possible to measure the level of the intensity of the variables included in the SATAQ 3 questionnaire. This variables have an association with various sources of internalization of the socio-cultural norm of body image and physical appearance of Polish men and women in their adolescence and adulthood.
It seemed to be important to develop Polish adaptation and standardization of the tool with proven psychometric properties, which can be used for measuring the socio-cultural norms regarding body image and physical appearance. Nevertheless, further analyses and observations on use of SATAQ 3 should be conducted on various populations of Poles in order to enrich this tool with the development of norms for individual age categories: from early through late adolescence to young adulthood and mature life.

\section{ENDNOTE}

1 Polish-language versions of SATAQ 3 is downloadable at https://pracowniatestow.pl/pl/p/Kwestionariusz-SATAQ-3/249

\section{References}

American Psychological Association (2013). Raport na temat seksualizacji dziewcząt [Report on the sexualization of girls]. In Stowarzyszenie Twoja Sprawa (Ed.), Odebrana niewinność. O seksualizacji kobiet i dziewcząt we wspótczesnej kulturze. Raporty [Innocence received. The sexualization of women and girls in contemporary culture. Reports] (pp. 11-61). Warszawa: Stowarzyszenie Twoja Sprawa.

Bair, C., Kelly, N., Serdar, K., \& Mazzeo, S. (2012). Does the internet function like magazines? An exploration of image-focused media, eating pathology, and body dissatisfaction. Eating Behaviours, 13, 398401. https://doi.org/10.1016/j.eatbeh.2012.06.003

Cash, T. F. (2011). Crucial considerations in the assessment of body image. In T. F. Cash \& L. Smolak (Eds.), Body image: a handbook of science, practice, and prevention (pp. 129-137). New York, NY: Guilford Press.

Clark, L., \& Tiggemann, M. (2008). Sociocultural and individual psychological predictors of body image in young girls: a prospective study. Devel- 
Bernadetta Izydorczyk, Sebastian Lizińczyk opmental Psychology, 44, 1124-1134. https://doi. org/10.1037/0012-1649.44.4.1124

Cohen, R., \& Blaszczynski, A. (2015). Comparative effects of Facebook and conventional media on body image dissatisfaction. Journal of Eating Disorders, 3, 1-11. https://doi.org/10.1186/s40337-015-0061-3

Cohen, R., Fardouly, J., Newton-John, T., \& Slater, A. (2019). Bo Po on Instagram: an experimental investigation of the effects of viewing body positive content on young women's mood and body image. New Media \& Society, 21, 1546-1564. https:// doi.org/10.1177/1461444819826530

Cohen, R., Newton-John, T., \& Slater, A. (2017). The relationship between Facebook and Instagram appearance-focused activities and body image concerns in young women. Body Image, 23, 183187. https://doi.org/10.1016/j.bodyim.2017.10.002

Cohen, R., Newton-John, T., \& Slater, A. (2018). 'Selfie'objectification: the role of selfies in self-objectification and disordered eating in young women. Computers in Human Behavior, 79, 68-74. https://doi. org/10.1016/j.chb.2017.10.027

Cusumano, D. L., \& Thompson, J. K. (1997). Body image and body shape ideals in magazines: exposure, awareness, and internalization. Sex Roles, 37, 701-721. https://doi.org/10.1007/BF02936336

Czepczor, K., Kościcka, K., \& Brytek-Matera, A. (2016). Społeczno-kulturowe postawy wobec własnego wyglądu i niezadowolenie z ciała u kobiet i mężczyzn w okresie późnej adolescencji: badania wstępne [The sociocultural attitudes towards appearance and body dissatisfaction among late adolescence: a pilot study]. Polskie Forum Psychologiczne, 21, 364-377. https://doi.org/10.14656/PFP20160303

Fardouly, J., Pinkus, R. T., \& Vartanian, L. R. (2017). The impact of appearance comparisons made through social media, traditional media, and in person in women's everyday lives. Body Image, 20, 31-39. https://doi.org/10.1016/j.bodyim.2016.11.002

Fardouly, J., \& Vartanian, L. R. (2015). Negative comparisons about one's appearance mediate the relationship between Facebook usage and body image concerns. Body Image, 12, 82-88. https://doi. org/10.1016/j.bodyim.2014.10.004

Ferguson, C. J., Winegard, B., \& Winegard, M. (2011). Who is the fairest one of all? How evolution guides peer and media influences on female body dissatisfaction. Review of General Psychology, 15, 11-28. https://doi.org/10.1037/a0022607

Finne, E., Bucksch, J., Lampert, T., \& Kolip, P. (2011). Age, puberty, body dissatisfaction and psychical activity decline in adolescents. Results of German Health Interview and Examination Survey (KIGGS). International Journal of Behavioral Nutrition and Physical Activity, 8, 119-133. https://doi. org/10.1186/1479-5868-8-119

Gajtkowska, M. (2013). Obraz własnego ciała współczesnej młodzieży a kultura popularna. Bada- nia własne [Self-image body of contemporary youth and pop culture. Own research]. Kultura, Spoteczeństwo, Edukacja, 2, 103-118. https://doi. org $/ 10.14746 /$ kse.2013.4.2.07

Garner, D. M. (2004). EDI-3. Eating Disorders Inventory. Lutz, FL: Psychological Assessment Resources, Inc. Głogowska, J., \& Zatorska, A. (2016). Wizerunek ciała dziewcząt w wieku 8-9 lat [Body image of girls aged 8-9 years]. Zeszyty Naukowe WSKFiT, 11, 29-34.

Grabe, S., Ward, L., \& Hyde, J. (2008). The role of the media in body image concerns among women: a meta-analysis of experimental and correlational studies. Psychological Bulletin, 134, 460-476. https:// doi.org/10.1037/0033-2909.134.3.460

Heinberg, L. J., Thompson, J. K., \& Stormer, S. (1995). Development and validation of the Sociocultural Attitudes Towards Appearance Questionnaire (SATAQ). International Journal of Eating Disorders, 17, 81-89. https://doi.org/10.1002/1098-108X(199501)17:1<81:: AID-EAT2260170111>3.0.CO;2-Y

Heinberg, L., Coughlin, J., Pinto, A. M., \& Guarda, A. S. (2008). Validation and predictive utility of the Sociocultural Attitudes Toward Appearance Questionnaire for Eating Disorders (SATAQ-ED): Internalization of sociocultural ideals predicts weight gain. Body Image, 5, 279-290. https://doi. org/10.1016/j.bodyim.2008.02.001

Hornowska, E., \& Paluchowski, W. J. (2004). Kulturowa adaptacja testów psychologicznych [Cultural adaptation of psychological tests]. In J. Brzeziński (Ed.), Metodologia badań psychologicznych. Wybór testów [Methodology of psychological research. Choice of tests] (pp. 151-191). Warszawa: Wydawnictwo Naukowe PWN.

Izydorczyk, B. (2014). Postawy i zachowania wobec wtasnego ciała w zaburzeniach odżywiania [Attitudes and behaviors towards one's own body in eating disorders]. Warszawa: Wydawnictwo Naukowe PWN.

Izydorczyk, B. (2015). Psychological and socio-cultural risk factors for developing negative attitude and anti-health behavior toward the body in young women. Polish Psychological Bulletin, 46, 555-572. https://doi.org/10.1515/ppb-2015-0062

Izydorczyk, B., \& Rybicka-Klimczyk, A. (2009). Poznawcze aspekty obrazu ciała u kobiet a zaburzenia odżywiania [Cognitive aspects of women's body image and eating disorders]. Endokrynologia Polska, 60, 287-294.

Jones, D. C., \& Crawford, J. K. (2006). The peer appearance culture during adolescence: gender and body mass variations. Journal of Youth and Adolescence, 35, 257-269. https://doi.org/10.1007/s10964-005-9006-5

Józefik, B. (2014). Kultura, ciało, (nie)jedzenie. Terapia. Perspektywa narracyjno-konstrukcjonistyczna w zaburzeniach odżywiania [Culture, body, (not)food. Therapy. Narrative-constructivist perspective on eating disorders]. Kraków: Wydawnictwo Naukowe Uniwersytetu Jagiellońskiego. 
Knauss, C., Paxton, S. J., \& Alsaker, F. D. (2009). Validation of the German version of the Sociocultural Attitudes Towards Appearance Questionnaire (SATAQ-G). Body Image, 6, 113-120. https://doi. org/10.1016/j.bodyim.2009.01.002.

Levine, M. P., \& Murnen, S. K. (2009). Everybody knows that mass media are/are not [pick one] a cause of eating disorders: a critical review of evidence for a causal link between media, negative body image, and disordered eating in females. Journal of Social and Clinical Psychology, 28, 9-42. https://doi.org/10.1521/jscp.2009.28.1.9

Levine, M. P., \& Smolak, L. (2006). The prevention of eating problems and eating disorders: theory, research, and practice. Mahwah, NJ: Lawrence Erlbaum Associates.

Levine, M. P., Smolak, L., \& Hayden, H. (1994). The relation of sociocultural factors to eating attitudes and behaviors among middle school girls. The Journal of Early Adolescence, 14, 471-490. https:// doi.org/10.1177/0272431694014004004

Lipowska, M., \& Lipowski, M. (2013). Polish normalization of the Body Esteem Scale. Health Psychology Report, 1, 73-81. https://doi.org/10.5114/ hpr.2013.40471

Mabe, A. G., Forney, K. J., \& Keel, P. K. (2014). Do you "like" my photo? Facebook use maintains eating disorder risk. International Journal of Eating Disorders, 47, 516-523. https://doi.org/10.1002/eat.22254

McCabe, M. P., \& Ricciardelli, L. A. (2004). Body image dissatisfaction among males across the lifespan: a review of past literature. Journal of Psychosomatic Research, 56, 675-685. https://doi.org/10.1016/ S0022-3999(03)00129-6

McLean, S. A., Paxton, S. J., Wertheim, E. H., \& Masters, J. (2015). Photoshopping the selfie: Self photo editing and photo investment are associated with body dissatisfaction in adolescent girls. International Journal of Eating Disorders, 48, 1132-1140. https://doi.org/10.1002/eat.22449

Mond, J., van den Berg, P., Boutelle, K., Hannan, P., \& Neumark-Sztainer, D. (2011). Obesity, body dissatisfaction, and emotional well-being in early and late adolescence: finding from the project EAT study. Journal of Adolescent Health, 48, 373-378. https://doi.org/10.1016/j.jadohealth.2010.07.022

Papadopoulos, L. (2010). Sexualization of young people review. London: Home Office Publication.

Rodgers, R., Chabrol, H., \& Paxton, S. J. (2011). An exploration of the tripartite influence model of body dissatisfaction and disordered eating among Australian and French college women. Body Image, 8, 208-215. https://doi.org/10.1016/j.bodyim.2011.04.009

Sánchez-Carracedo, D., Barrada, J. R., López-Guimerà, G., Fauquet, J., Almenara, C. A., \& Trepat, E. (2012). Analysis of the factor structure of the Sociocultural Attitudes Towards Appearance Questionnaire (SATAQ-3) in Spanish secondary-school students through exploratory structural equation modeling. Body Image, 9, 163-171. https://doi.org/ 10.1016/j.bodyim.2011.10.002

Saunders, J. F., \& Frazier, L. D. (2017). Body dissatisfaction in early adolescence: the coactive roles of cognitive and sociocultural factors. Journal of Youth and Adolescence, 46, 1246-1261. https://doi. org/10.1007/s10964-016-0559-2

Schaefer, L. M., Harriger, J. A., Heinberg, L. J., Soderberg, T., \& Thompson, K. J. (2017). Development and validation of the sociocultural attitudes towards appearance questionnaire-4-revised (SATAQ-4R). International Journal of Eating Disorders, 50, 104-117. https://doi.org/10.1002/eat.22590

Slater, A., Cole, N., \& Fardouly, J. (2019). The effect of exposure to parodies of thin-ideal images on young women's body image and mood. Body Image, 29, 82-89. https://doi.org/10.1016/j.bodyim.2019.03.001

Stice, E., Marti, C. N., \& Rohde, P. (2013). Prevalence, incidence, impairment, and course of the proposed DSM-5 eating disorder diagnoses in an 8-year prospective community study of young women. Journal of Abnormal Psychology, 122, 445457. https://doi.org/10.1037/a0030679

Striegel-Moore, R. H., Rosselli, F., Perrin, N., DeBar, L., Wilson, G. T., May, A., \& Kraemer, H. C. (2009). Gender difference in the prevalence of eating disorder symptoms. International Journal of Eating Disorders, 42, 471-474. https://doi.org/10.1002/ eat.20625

Tatangelo, G., McCabe, M., Mellor, D., \& Mealey, A. (2016). A systematic review of body dissatisfaction and sociocultural messages related to the body among preschool children. Body Image, 18, 86-95. https://doi.org/10.1016/j.bodyim.2016.06.003

Thompson, J. K., Heinberg, L. J., Altabe, M. N., \& Tantleff-Dunn, S. (1999). Exacting beauty: Theory, assessment, and treatment of body image disturbance. Washington, DC: American Psychological Association.

Thompson, I. K., van den Berg, P., Roehrig, M., Guarda, A. S., \& Heinberg, L. J. (2004). The Sociocultural Attitudes Towards Appearance Scale-3 (SATAQ-3): Development and validation. The International Journal of Eating Disorders, 35, 293304. https://doi.org/10.1002/eat.10257

Thomsen, S. R., Weber, M. M., \& Brown, L. B. (2002). The relationship between reading beauty and fashion magazines and the use of pathogenic dieting methods among adolescent females. Adolescence, 37, 1-18.

Tiggemann, M. (2003). Media exposure, body dissatisfaction and disordered eating: Television and magazines are not the same. European Eating Disorders Review, 11, 418-430. https://doi.org/10.1002/ erv. 502

Tiggemann, M., \& Brown, Z. (2018). Labelling fashion magazine advertisements: Effectiveness of differ-
The Polish adaptation of the SATAQ 3 
ent label formats on social comparison and body dissatisfaction. Body Image, 25, 97-102. https:// doi.org/10.1016/j.bodyim.2018.02.010

Trojanowska, P. (2014). Seksualizacja dzieci i młodzieży - przyczyny, przejawy, konsekwencje i propozycje przeciwdziałania [The sexualisation of children and young people - causes, symptoms, consequences and prevention proposals]. Dziecko krzywdzone. Teoria, badania, praktyka, 13, 55-78.

Uchôa, F. N. M., Uchôa, N. M., Daniele, T. M. D. C., Lustosa, R. P., Garrido, N. D., Deana, N. F., Ara-

Bernadetta Izydorczyk, Sebastian Lizińczyk nha, Á. C. M.; \& Alves, N.(2019). Influence of the mass media and body dissatisfaction on the risk in adolescents of developing eating disorders. International Journal of Environmental Research and Public Health, 16, E1508. https://doi.org/10.3390/ ijerph 16091508

Vandenbosch, L., \& Eggermont, S. (2013). Sexualization of adolescent boys: Media exposure and boys' internalization of appearance ideals, self-objectification, and body surveillance. Men and Masculinities, 16, 283-306. https://doi.org/10.1177/1097184X13477866

Vandenbosch, L., Vervloessem, D., \& Eggermont, S. (2013). "I might get your heart racing in my skintight jeans": Sexualization on music entertainment television. Communication Studies, 64, 178194. https://doi.org/10.1080/10510974.2012.755640

Ward, M. (2016). Media and sexualization: state of empirical research, 1995-2015. The Journal of Sex Research, 53, 560-577. https://doi.org/10.1080/0022 4499.2016.1142496

Żechowski, C. (2008). Polska wersja Kwestionariusza Zaburzeń Odżywiania (EDI) - adaptacja i normalizacja [Polish version of Eating Disorder Inventory - adaptation and normalization]. Psychiatria Polska, 42, 179-193. 